e-makâlât Mezhep Araştırmaları, VII/2 (Güz 2014), ss. 149-173.

ISSN 1309-5803 | www.emakalat.com

\title{
MAHFUZÂT: \\ TUNUS VE TUNUS İBADÎLERİ ÜZERİNE NOTLAR ${ }^{1}$
}

\author{
Mehmet Mahfuz SÖYLEMEZ ${ }^{2}$
}

\section{Giriş}

Günümüzde Kuzey Afrika İbadîlerinin üç bölgede yaşadıkları bilinmektedir. Bunlardan nüfus olarak en kalabalığı Cezayir'de bulunmakta olup ülke nüfusunun yaklaş1k \%5'ini teşkil etmektedir. 2014 yılı yazında buraya bir seyahat düzenlemiş ve aralarında bir hafta kalmış, gözlemlerimizi de bir yazı halinde yayınlamıştık. İkinci önemli küme ise Libya'da bulunmaktadır. Cebelu'n-Nefusa bölgesinde yaşayan bu küme hakkında özellikle onlardan biri olan ve Osmanlı döneminde mebusluk yapan Süleyman Barunî Paşa bağlamında bir çalışma yürütmekteyiz. İkmal edilir edilmez siz değerli okurlarımıza arz edeceğiz. Üçüncü kümeye gelince elinizdeki yazının konusu olan Tunus'un Cirbe adasında yaşamaktadır. Buraya İstanbul Üniversitesi adına yürüttüğümüz "İbadîlerin Tarih ve Kuran Algıları" başlıklı proje kapsamında Nisan 2015 tarihinde bir seyahat düzenledik. Elinizdeki yazı bu bağlamda kaleme alınmıştır. Seyahatimiz esnasında tuttuğumuz notlara geçmeden önce Tunus ve özellikle de Cirbe Adası ve buranın İslamlaşma süreci, tarihi ve günümüzdeki durumu hakkında kısa bilgi vermek istiyoruz.

1 Bizden önce Tunus'a giden Muş Alpaslan Üniversitesi İslam Tarihi Araştırma Görevlisi sevgili Ahmet İĞDİnin deneyimleri ve kişisel bağlantılarından istifade ettik. Burada kendisine teşekkür ederim.

2 Prof. Dr. İstanbul Üniversitesi İlahiyat Fakültesi Öğretim Üyesi; YDÜ İlahiyat Fakültesi Öğretim Üyesi. mehmetmahfuz@gmail.com 
Tunus'a İslam'ın girişi oldukça eskidir. Hz. Ömer döneminde M1sir'ın fethi tamamlandıktan sonra İslam orduları Libya üzerinden Tunus bölgesine gelmiş ve Cirbe Adası dışında kalan bölgelerin fethi hicri 23/643 tarihinde tamamlanmıştır. Hz. Osman'in hilafetinin ikinci altıncı yılından sonra İslam devletinin sınırları içerisinde başlayan iç çekişmeler nedeniyle fetihler durma noktasına gelmiştir. $\mathrm{Hz}$. Ali'nin vefatından sonra hilafete gelen $\mathrm{Hz}$. Hasan'in Muaviye ile anlaşarak ona biat etmesiyle yeniden iç bütünlük sağlanmış oldu. $\mathrm{Bu}$ dönemden itibaren de fetihler yeniden başladı. Bu bağlamda Cirbe Adası hicri 46/665 y1lında Muaviye b. Hudeyc es-Sekunî elKindî tarafından İslam topraklarının bir parçası haline geldi. Daha sonra Abbasîler ve Ağlebîlerin bir parçası olan Tunus, sırasıyla Fatımiler, Senâhice, Muvahhitler ve Hafsîlerin hâkimiyetinde kalmıştır. Bir dönem İspanyollar tarafından işgale uğrayan ülke, Osmanl1nın desteğiyle işgalden kurtulmuş ve bu devletin bir parçası haline gelmiştir.

Yaklaşık dört yüz yıl Osmanlı hâkimiyetinde kalan Tunus 1881 yılında Fransa ile yapılan Bardo antlaşması ile onlara devredilmiştir. 1956 yılında bağımsızlığını elde edinceye kadar Fransa'nın hâkimiyetinde kalan Tunus, uzun yıllar Burgiba tarafından yönetilmiştir. Bu dönemde Fransız tipi katı jakoben laikliği uyguladığ için belli yaşın üzerindeki insanlara ancak hacca gitme izni veriliyor, bırakın başörtülü hanım efendilerin kamusal alan denilen hakim unsurların yetki sahasına girmeyi, dışarıda bile dolaşmalarına izin verilmemekteydi. Burgiba'yı askeri darbe ile görevden uzaklaşt1ran Zeynel Abidin b. Ali yirmi üç yıl Tunus'u tek adam olarak idare etmiştir. Onun döneminde ise Tunus'ta başörtüsü yasağında kısmen yumuşama görülse de peçenin yasaklanması, devlet dairelerinde başörtülü hanımların çalışmasına izin verilmemesi, sultayı elinde bulunduran ailenin yolsuzlukları, insan hakları ihlalleri, İslami kesimlerin siyasetin dişında tutulması, baskıya maruz bırakılmaları hep gündemde olmuştur. O günlerde biriken patlama 2011 yılında bir halk isyanına dönüştü. Buazizî adında bir delikanlı üniversite mezunu olmasına rağmen bulamamasından şikâyet ederek kendisini Sidibuzid Kenti'nde yaktı. Bu hadise, bir ihtilali tetik- 
ledi ve ülkeyi 23 yıldan beri yöneten Zeynel Abidin, aile efradını alarak Fransa'ya sığınmak zorunda kaldı. Diğer Arap ülkelerini de etkileyen bu hadise oralarda da bir dizi halk hareketine neden oldu. Bu hareketler o ülkelerde daha çok kan ve gözyaşı ile istikrarsızlığa neden olsa da Tunus'ta özellikle halkın ferasetli davranması nedeniyle farklı şekilde seyretti. Zira olaylar devam ederken halk, polis ile göstericiler arasında bir sokak savaşı çıkmaması için hem göstericileri yatıştırmaya çalıştı, hem de güvenlik görevlilerini teskin ederken kendilerine günlerce yemek ve çay ikram ederek aynı geminin içiresinde olduklarını ve birlikte hareket etmeleri gerektiğini gösterdi.

Devrimden sonra hızla gerçek demokrasiye doğru yol alan Tunus'ta, bilge duruşuyla dikkatleri üzerinde toplayan Gannuşî’nin liderliğini yaptığı Nahda partisi oyların önemli bir kısmını alarak iktidara geldi. Nahda, Misır örneğinden de istifade ederek Tunus'u oluşturan siyasi renklerin tamamını bir şekilde yönetime katmaya çalışmakla birlikte hâkim unsur kendisi oldu. Ancak beklenen sıçramayı yapamadığı için de 2015 yılında yapılan seçimlerde parlamentonun çoğunluğunu Nida partisine biraktı ve hükümet onlar tarafindan kuruldu.

Başkent Tunus'un yanı sıra Gabes, Susa, Hamamat, Sifaks ve Kayrevân'in en önemli şehirlerini teşkil ettiği Tunus, yaklaşık olarak 11.000.000 kadar bir nüfusa sahiptir. Tunus'un başkenti 1.000.000'dan fazla nüfusu bulunmakta olup ülke ile aynı ismi taşımaktadır.

Tunus'un asıl sakinlerini günümüzde Araplar oluşturmaktadır. Bunların bir kısmı Arap kökenli olsalar da önemli bir bölümünün Emaziğ kökenli iken zamanla Araplaşmış olduklarını tahmin etmek zor değildir. Arapların yanı sıra Tunus'ta Osmanlı döneminden kalma bazı Türk aileler de yaşamaktadır. Bunlar günümüzde Türkçe konuşmamakla beraber kendilerini Türk olarak hissetmektedirler. Keza burada Fransız ve İtalyan ailelerine mensup bazı zevatın yaşadığı da bilinmektedir. 


\section{Tunus Seyahati 14/04/2015}

İstanbul Üniversitesi İlahiyat Fakültesi öğretim üyesi Sayın Şevket Kotan beyefendi ile birlikte 14 Nisan 2015 tarihinde İstanbul Atatürk Havaalanından 13:45 uçağıyla Tunus'a gitmek üzere hareket ettik. Uçakta genelde Tunus üzere seyreden bir sohbet eşliğinde Tunus-Kartac havaalanına indik. Daha modern olmasını beklediğim, ancak sıradan ve aynı zamanda Türkiye'nin çok gerisinde olduğunu gördüğüm havaalanında pasaport işlemlerinden sonra bizi almaya gelen gençlerle buluştuk. Bizim fakülteden Ramazan Yıld1rım hocanın mahdumu sevgili Yasir ve aynı evi paylaştığı Safa bizi karş1ladılar. Yasir Zeytune Üniversitesi Hadara el-İslamiyye Fakültesi okurken Safa ise 9 Avril (Tunus) Üniversitesi İngiliz Dilinde eğitim görmekteydi. ${ }^{3}$

Başkent Tunus'un bende bıraktığı ilk izlenime gelince; etrafta dolaşan insanlar özellikle de hanımefendilerin kıyafetleri sizi bir Avrupa ülkesindeymiş gibi karş1lasa da cadde ve sokaklar, binalar, temizlik, trafiğin akışı, neredeyse her sokak başında duran polisler size güvenlik sorunlarının yaşanmakta olduğu bir doğu ülkesinde olduğunuzu haykırıyor. Eşyalarımızı Lafeyat Semti'nde bulunan gençlere ait eve koyduktan sonra şehrin merkezine doğru gitmek için hareket ettik. Takip ettiğimiz caddenin üzerinde bulunan devasa Havra Tunus'ta önemli oranda Yahudi'nin yaşadığını gösterse de bunların giderek azaldığı ve özellikle Fransa ile İtalya'ya göç etmeye çalıştıkları kaydedilmektedir. Bu caddenin sağ ve solunda uzanan binaların tamamı gotik mimari tarzına sahip Fransız usulü idi. Buradan ulaştığınız Burgiba Caddesi ise bu tarzın en yoğun olarak kendini gösterdiği kısmı teşkil ediyordu. Suku'1-Medine veya Suku'z-Zeytune'nin girişinden başlayan ve kuzeye doğru inildiğinde Saat Kulesine kadar devam eden bu caddenin Fransiz kent anlay1şindan mülhem olarak muhtemelen Paris'in Şanzelize denilen ana bulvarına öykünerek inşa edildiği anlaşılmaktadır. Caddenin iki tarafında çay bahçeleri, lokantalar, dondurmacılar yer almaktadır.

\footnotetext{
${ }^{3}$ Her ikisine de buradan teşekkür ediyorum.
} 
Buraya gelmişken yemeği de aradan çıkaralım dedik ve nezih olduğunu düşündüğümüz bir lokantaya daldık. Yemek olarak talep ettiğimiz kuskus "maahut" yani balıklı kuskus son zamanlarda yediğim en kötü yemek olsa da karnımızı doyurmuş olduk. Bu caddenin üzerinde Fransızlar tarafından yaptırılan ve Fransızların hala burada olduklarını adeta haykıran devasa kilise ise caddenin en dikkat çeken binası olarak kendisini göstermektedir.

Zeytune Camisi'ne ${ }^{4}$ gitmek için geçtiğiniz devasa kapı aslında burada bir zamanlar surla kuşatılmış bir iç kalenin varlığını ve Zeytune Caminin bu alanın merkez noktası olduğunu göstermektedir. Günümüzde buraya el-Medine biraz yukarısına ise el-Kasba veya el-Kasaba denilmektedir. Bilindiği gibi Kuzey Afrika'daki el-Kasaba ifadesi doğu kentlerimizde şehir merkezi için kullanılan Şehristan ifadesinin karş1lığ olarak kullanılmaktadır.

Yüzlerce yıl öncesini andıran dar ve birbirine bitişik küçük dükkân (hanut) lardan oluşan Zeytune'nin etrafındaki çarşı, bizim İslam şehirlerinin tamamında alışageldiğimiz kapalı çarşı geleneğinin bir devamı mahiyetindedir. Bir zamanlar arasta sisteminin hâkim olduğu bu çarşıda günümüzde neredeyse sadece turistlere yönelik hediyelik eşya satılmaktadır. Zeytune camisi ise bu küçük dükkân yumağının ortasında devasa bir mabet olarak hala varlığını korumaktadır. İnşa edildiği yer bir tepelik olduğu için ön kısmı kot olarak arka kısmına göre düşük olduğundan bir tesviye sağlanmıştır. Nispeten yüksek sayılan merdivenlerden camiye girilmektedir. Caminin önünde ise dini eserler satan bir kitapçı dükkânı bulun-

4 Zeytune Camiinin, adını, kurulduğu yerde bulunan zeytin ağacından aldığı rivayet edilmektedir. Bu rivayetlere göre Müslümanlar bölgenin fethini tamamlayınca burada bir cami inşa etmeye karar verirler. Cami münzevi rahiplerden birinin altında ibadet ettiği bir zeytin ağacının yanında inşa edilmisstir. Adını işte bu Zeytin ağacından almaktadır. Tunus şehri de zamanla bu mabedin etrafında biçimlenmiştir. [Bkz. Muhammed b. el-Hoca, Safahat min tarih Tunus, (takdim: tahkik: Hammâdî es-Sahilî-Ceylanî b. el-Hac Yahya), Beyrut 1986, 283.] İslam kentlerinin inşasında genelde buna benzer mitolojik anlatıların aktarılması bir gelenek haline gelmiştir. Ancak Hristiyanlara merkezi bir rol biçen bu ve benzeri rivayetlerin doğruyu yansıtıp yansitmadığı hep tartışma konusu olmuştur. 
maktadır. Kitapçıyı görmüşken Tunuslu ilim adamlarının yazdığı siyer kitapları var mı diye sormak istedim, fakat bulamadım. Zaten Tunus neşriyat hususunda oldukça zayıf bir ülkedir. Kaldı ki basılanlar da, diğer ülkelerde tab' edilenlerle mukayese edildiğinde son derece pahalıdir.

Zeytune Camii'nin içi muhteşem, kendinizi Kurtuba Ulu Camii veya el-Hamra'nın işlemelerinin dayandığı kökende hissediyorsunuz. Caminin içerisi yüzlerce yıl öncesindeki mabetleri andırmaktadır. Son bir ay öncesine kadar bu sütunların üzerinde ders halkalarının isimleri bile varmıs. Hadis halkası, siyer halkası, tefsir halkası vs. Ancak Bardo müzesinde turistlere yönelik saldırı, bir nevi Tunus'un on bir eylülü olmuş bir dizi güvenlik önlemleri ile birlikte buradaki dersler de yasaklanmıs. Namaz kılmak için gittiğimiz caminin avlusunda tanıştığımız beyefendi çekinerek; etrafına baka baka ve de sesini de kısarak "aslında bu ders halkalarının laik devlet tarafından camii imamına yapılan baskı ile kaldırıldığını" anlattı. Caminin içerisindeki dolapların üzerinde bu ilim dallarının isimleri hala yazılı olarak dursa da dolaplar kapalı vaziyettedir. Mihrabın tezyini ise el-Hamra'yı andırmaktadır. Kullanılan sütun başları Roma tarzını, tavanı ise Misır Amr b. el-As Camii'ndeki tavanları andirmaktadır. Mihrabın etrafinda var olan iki kapı da aynen Kurtuba'daki mihrabı çağrıştırmaktadır. Zeytune Camii'nin içerisinde yer alan mihrabın üzerinde hicri 1211 tarihi kazınmış vaziyettedir. Bunun caminin inşa kitabesi değil de tamir kitabesi olduğu anlaş1maktadir. Caminin revaklı avlusunda ise Hindistan camilerinin avlusundaki gibi güvercinler yer almaktadır. Mabetlerimizde güvercinlerin bulunmasının nedeni kadim döneme, Hz. Peygamber'in hicretine kadar geri gitmektedir. Bilindiği gibi Hicret döneminde güvercinlerin, bir nevi Hz. Peygamberi düşmandan korumuş olmaları, ümmet nezdinde bu hayvanlara karşı ayrı bir sevginin oluşmasına sebep olmuştur. Hatta bazı İslam bölgelerinde güvercin eti bile yenmez. Bu da aslında bizde var olan vefayı göstermektedir. Zeytune camiinin kare biçimindeki kalın ve işlemeli minaresi Kuzey Afrika'nın tamamında karşımıza çıkmaktadır. Ne zaman inşa edildiği sorusuna gelince; Tunus Cami' el-Kebir'i olarak da bilinen bu ulu 
mabet, ilk kez Emevî valilerinden Hasan b. Numan tarafından inşa edilmiş olsa da daha sonra aynı devletin valilerinden İbnu'l-Habhâb tarafından yenilenmiştir. İleriki tarihlerde Abbasiler dönemi başta olmak üzere birçok kez tamir görmüştür. Zeytune, Kayravan ulu camiinden yaklaşık yirmi y1l sonra inşa edilmiş olup, Osmanlı döneminin izlerini de üzerinde taşımaktadır. ${ }^{5}$

Zeytune'den sonra buraya çok yakın olan, İbadîlere ait tarihi camii, yani Hentati'yi ziyaret etmeye karar verdik. Suku'1Medine'nin yani tarihi çarşının içerisinde yer alan cami, başkent Tunus'taki tek İbadî mabedi olma özelliğine sahiptir. Bu cami ile buranin cemaatinden olan akademisyen kökenli Dr. Ferhat Ca'birînnin iletişim bilgilerini Muhammed Babaammî, sevgili Ahmet İğdi ile Züheyr et-Tiğlat'dan almıştık. Maalesef birkaç kez aramamıza rağmen Dr. Ferhat'a ulaşamamıştık. Züheyr bey bize "namaz vakitlerinde camiye giderseniz kendisiyle görüşebilirsiniz" demişti. Camiye geldiğimizde ise maalesef caminin kapalı olduğunu gördük. Orada bir delikanlı bizi biraz ileride bir dükkana yönlendirdi ve dükkan sahibinin caminin imamı ve adının Şeyh Lütfí olduğunu söyledi. Şeyh Lütfi'ye Ferhat Ca'biri ile görüşmek istediğimizi, İbadîlik çalıştığımızı söyleyip İslamî İimler Dergisi’nin henüz neşredilen İbadîyye sayısından bir nüsha verince çok ilgilendi ve Ferhat hocanın Uman'dan bu gün döndüğünü, yorgun olduğu için akşam camiye gelemeyeceğini, ertesi gün gelmemizin daha uygun olacağını söyledi. Böylece Ferhat beyi göremeden oradan ayrıldık.

Zeytune'nin merkezini teşkil ettiği el-Kasba bir surla kuşatılmıştır. Bu surun Burgiba caddesine açılan kısmı günümüzde ayakta durmamaktadır. Öyle anlaşılıyor ki Burgiba Caddesi açıldığı zaman sur yıkılmıştır. Bu da, bizde İstanbul Fatih’teki Vatan Caddesi açı1dığı zaman yıkılan bir çok tarihi mekan gibi, Burgiba caddesi açılırken burada da birçok tarihi mekânın yıkıldığını göstermektedir. elKasba'nın güney surlarının bir kısmı ise hala ayaktadır. Kasaba'nın

5 Zeytune Camisi'nin inşası ve geçirdiği tamirler hakkında geniş bilgi için bkz. Muhammed b. el-Hoca, 283-296. 
bu bölgesinde yani güney cenahında Tunus Dayılarından ${ }^{6}$ biri tarafından inşa edilmiş bir cami yer almaktadır. Bu caminin etrafında bu gün Savunma Bakanlığı (Vizaretu'd-Difa') ve Maliye Bakanlığ1 Vüzaretu'l-Maliyye yer almaktadır. Bu iki bakanlığın güneyinde ise Tunus Belediyesi'ne ait muhteşem bir bina bulunmaktadır. Yüksek bir tepenin üzerinde inşa edilen Belediye binasının önünde ise oldukça geniş bir meydan mevcuttur. Bu bölgede bulunan resmi dairelerin etrafı tel örgülerle kapatılmış ve polislerle abluka altına alınmıştır. Bir tek bu bile Tunus'ta yakın zamanda oldukça sert hadiselerin yaşadığını anlatmak için kafi veridir. Belediyenin hemen yanında ise hala kullanılmakta olan bir Osmanlı mektebi, Medresetu's-Sadıkiyye yer almaktadır. Muhtessem bir mimariye sahip olan bu okul, günümüzde lise olarak kullanılmaktadır. Son Osmanlı bürokratlarından Hayrettin Paşa tarafından 1875 tarihinde inşa edilen bu okul, bulunduğu mekânın en güzel binasıdır. ${ }^{7}$ Bir önceki cumhurbaşkanımız Sayın Abdullah Gül buraya gelmiş ve okulun bilgisayarlarını yenilemiştir. Aynı bölgede bulunan ve günümüzde polisler tarafindan kullanılan bir binanın içerisinde Kuzey Afrika'ya Malikî mezhebini yayan İmam Ali b. Zeyd'in türbesi yer almaktadır. Bilindiği gibi hicri 183 yılında vefat eden Ali b. Zeyd, 178 yılında vefat eden hocası İmam Malik'ten Muvatta'yı rivayet eden önemli şahıslardandır. Kendisinden Behlul b. Raşid ile Esed b. el-Furat Muvatta'yı rivayet etmisslerdir. Bu kabir bizde bir zamanlar burada bir kabristanın bulunduğu ve bunun dişındaki kabirlerin yok edildiği izlenimi uyandırdı.

Ertesi sabah yani 15/04/2015 tarihinde erkenden kalktık. Önce Zeytune Üniversitesi'ne gittik. Üniversite'ye İstanbul'da tanıştığımız Uslulu'd-din Fakültesi Hadara bölümü başkanı Dr. Ali es-Sulî ile yine Zeytune Üniversitesi Kulliyetu'l-Hadare el-İslamiyye'nin dekanı Dr. Munir Ruvîs ile görüşmeye gittik. Üniversiteye vardığımızda

${ }^{6}$ Dayı Osmanlının Tunus idari sisteminde bey anlamına gelen bir yöneticidir. Bkz. Mehmet Maksutoğlu, "Tunus'ta Dayıların Ortaya Çıkışı, Ankara Üniversitesi ilahiyat Fakültesi Dergisi, Ankara 1966, XIV, ss.189-202.

7 Sadıkıyye Mederesesi'nin kuruluş nedeni, tarihi ve Osmanlı dönemindeki müfredatı hakkında geniş bilgi için bkz. Muhammed b. el-Hoca, 309-324. 
Dr. Ali es-Sulî'nin derste olduğunu, saat on birde buluşabileceğimizi söyledikleri için var olan zamanımızı değerlendirmeye çalışırken İbn Haldun Amfisinde (Medrecu İbn Haldun) bir panel olduğunu fark eden Şevket hocamı takip ederek amfiye girdik. Konu son derece çekiciydi. Avrupa'da Müslüman azınlıklar meselesi ele alınmaktayd1. Fransa'da yakın zamanda yaşanan sorunların bu panelin yapılmasına neden olduğu anlaşılmaktadır. İçeri girdiğimizde henüz başladığ anlaşılan panelde Dr. Tevfik Burgiba konuşuyordu. Dr. Tevfik Burgiba, özetle Avrupa'da önemli bir Müslüman kitlenin yaşadığını anlattı, sadece Fransa'da 2200 caminin bulunduğunu, diğer Avrupa ülkelerinde de önemli bir Müslüman kitlenin yaşadığını tablolar üzerinde aktardı. Onun verdiği bilgilere göre İslam ülkelerinden Avrupa'ya hicret eden Müslümanlar arasında organize bir yap1 yoktur. Birbirlerinden kopuk yaşamaktadırlar. Zaten buraya göçler de genelde hemşeri ve akraba toplulukları şeklinde devam etmiştir. Bunlarla diğer Müslümanlar arasında diyalog olmadığı gibi Avrupa'ya yerleşen ilk nesil ile ikinci nesil arasında da iletişimsizlik söz konusudur. İkinci konuşmacı olan Dr. Muhammed Mestirî'nin "Müslümanlar ve Avrupa Devletlerindeki Vatandaşlik Hukuku" başlığ1 taşıyan konuşması ise daha ilgimi çekti. Zira Dr. Mestirî Avrupa'ya göç eden Müslümanların Avrupa yasalarının farkında olmadıklarını; Avrupa ülkelerinde vatandaşlık elde etmiş olmalarına rağmen bu vatandaşlığın anlamını dikkate almadıklarını anlatırken Avrupa ülkelerinin de Müslümanların varlığını göz ardı ettiğini ve sahip olduğu laikliği neredeyse diğer kimlikleri yok edecek kadar sert kullandığını söyledi. Avrupa ile burada yaşayan Müslüman azınlıkların karşılıklı olarak vatandaşlık kültürü inşa etmeleri, modernite ve modern vatandaşlığı öğrenmeleri gerektiğini, Avrupa'nın da Müslümanları asli vatandaşları olarak kabul etmesinin icap ettiğini ve Müslümanların taleplerini göz ardı etmemelerinin zorunlu olduğunu söylemesi çok önemliydi. İslamifobianın da ancak bu şekilde önüne geçilebileceğini söyleyen Dr. Mestirî, bu konuda özgürlükleri savunan Avrupalı elitlerden de faydalanılabileceğini ifade etti. 
Randevusuna zamanında gelmeyen Dr. Ali es-Sulî ile görüşmekten vazgeçince Zeytune'ye doğru gitmeye karar verdik. Bunun için de yol sormaya başladık. Her soruyu sorduğumuz beyefendinin bize yardım hususundaki istekliliği, hele yol sorarken, yolunu değiştirip bizi el-Kasba'ya kadar götüren beyefendinin yardımseverliği, Türkiye'den geldiğimizi söylerken yüzlerde açan beşaşet aslında Tunusluların yabancıya; Fransızlar kadar olmasa da Türklere karşı muhabbetini göstermesi açısından önem arz etmektedir. Bu arada bir de Mektebetu el-Vatanî'ye gitmiş olduk. Tunus milli kütüphanesi aynı zamanda tarihi Zeytune Kütüphanesi'nin yazmalarını da içermektedir. ${ }^{8}$ Devasa binanın giriş katı yazmalara, ikinci kat matbu eserlere ve tezlere, son kat ise süreli yayınlara ayrılmıştır. Kütüphane kapalı raf sistemiyle çalıştı̆̆ için kısa zamanlı çalışmalar için elverişli değildir. Matbu eserlerin sadece ilk elli sayfasının fotokopisine izin verilirken, tezlerin fotokopisi ise tamamen yasaktır. Fotokopi hizmeti sadece öğleye kadar verilmektedir. Kütüphane içinde bulunan bilgisayarlardan kitaplar taranabilmektedir. Ancak kataloglarda var olan kitapların bir kısmı kütüphanede bulunmayabilmektedir. Kütüphanenin altında bir yemekhane ve kantin de mevcuttur. Bu da kütüphanede uzun saatler çalışmak zorunda kalan araştırmacılar için kolaylık sağlamaktadır. Tunus Milli Kütüphanesi'nin en önemli özelliklerinden biri de başkentte yaşayan akademisyenlerin önemli bir kısmının çalışmak için burayı tercih etmesidir. Zira üniversitelerde çalışan akademisyenlerin çoğunun, fakültelerinde ofisleri bulunmamaktadır. Dolayısıyla onlar ya evlerinde çalışmak veya kütüphaneleri kullanmaktadırlar.

8 Oldukça köklü bir geçmişe sahip olan Zeytune Kütüphanesi'nin tarihi daha eski olsa da kaynaklarımızda daha çok Hafsîlerden Ebu'l-Faris Abdulaziz elHafsî tarafından 797/1395 tarihinde kurulduğu yer almaktadır. Torunu Ebu Amr Osman tarafından 839/1435 genişletilen kütüphane, 980/1572 tarihindeki İspanya işgali esnasında zarar görmüştür. Bu dönemde kitaplar tahrip edilmiş bir kısmı yakılmış bazısı ise parçalanarak caminin etrafına dağıtılmıştır. Rivayetlere göre caminin etrafından geçenler bu kitaplara basmadan gidecekleri mekâna ulaşamıyorlardı. Bu değerli kütüphane bu dönemde önemli ölçüde zarar görmüş olsa da kalan eserleriyle asırlarca ilim adamlarına hizmet vermeye devam etmiştir. Geniş bilgi için bkz. Muhammed b. elHoca, 296-309. 


\section{İbadîler İle Görüşme}

Paneli dinlerken bir ara ön tarafta Dr. Münir Ruvîs'in oturduğunu gördüm ve kendisine İstanbul'da iken getirmeyi vadettiğim dergiyi vererek Hentati Camisindeki randevumuza gitmek için çıktık. Caminin imamı Şeyh Lütfi bize Dr. Ferhat Cabirî'nin öğle vakti geleceğini söylediği için zamanından yaklaşık yarım saat önce oraya vardik. Ancak henüz kimse gelmediği için Suku'z-Zeytune'nin içerisinde bir kahvede gayet güzel bir kahve içerek biraz muhabbet ettikten sonra Şeyh Lütfi'nin dükkanına geldik. Bizi bekliyordu. Gayet güler yüzle bizi karşıladı ve dün kendisine hediye ettiğim makalelerden Şeyh İtfeyyiş'le ilgili olanını okuduğunu ve Dr. Ferhat ile irtibat kurduğunu, öğle namazında burada olacağını söyledi. Daha sonra dükkanın kapısına bir tahta gererek birlikte namaza gittik. Dükkanını kapatmayıp sadece "burada değilim, ancak uzakta da değilim" anlamına gelen tahtayı koyması etkileyiciydi. Son derece temiz ve nezih bir cami olan Hentati oldukça kalabalık bir cemaate sahipti. Caminin imamı İbadî olmakla birlikte cemaatin tamamı İbadîlerden oluşmuyordu. Benim sağımda bir İbadî dururken, solumda ise bir Sünni yani Malikî vardı. Namaza "Allahu Ekber" diye başlayan imamın arkasından cemaatin tamamının yüksek sesle "Allahu Ekber" diyerek katılması alışık olmadığım, etkileyici bir tabloydu. Namazın sonunda toplu duadan sonra, cemaat dağılınca Şeyh Lüfti bizi Dr. Ferhat ile tanıştırdı. Kendimizi tanıttıktan sonra Tunus'a İbadîleri ve İbadî cemaatini tanımak amacıyla geldiğimizi bu vesileyle kendisinden istifade etmek istediğimizi söyledim. Kedisiyle son derece güzel bir ropörtaj gerçekleştirdik. ${ }^{9}$

Tunus İbadîleri düşünsel anlamda aslında Cezayir İbadîleri ile aynı fikirlere sahiptirler. Rüstemiler'in ikinci imamı Abdulvahhab'ın seçimi hususunda meydana gelen iç çekişmeler sonucunda İbadîler İmam Abdulvahhâb'in imametine karşı olan Nukkariye ile onu destekleyen Vehbiyye olmak üzere ikiye bölünmüşlerdi. Ancak Nukka-

\footnotetext{
${ }^{9}$ Ferhat beyle gerçekleştirdiğimiz bu söyleşi için bkz. Mehmet Mahfuz Söylemez, “Dr. Ferhat Ca'birî ile Tunus İbadileri Üzerine Söyleşi”, Yakın Doğu Üniversitesi İlahiyat Fakültesi Dergisi, Yıl II, Sayı, Lefkoşa 2015.
} 
riye zamanla ağırlığını yitirmiş hatta kimi rivayetlere göre çoğunlukla Kuzey Afrika'nın hâkim kültürü olan Malikiliği benimsemiş iken Vehbiye ise günümüze kadar varlığını sürdürmüştür. Günümüzde Cerid, Cirbe ve Tunus'un Güney kısmında yaşayan İbadîler, genel nüfusun içerisinde çok az bir yekünü teşkil etmektedirler. Hatta kimisine göre yüzde birin altındadırlar. Dr. Ferhat Cabiri’ye göre ise ancak 150.000 kişi kadardırlar.

Tunus İbadîleri Cezayir İbadîlerinin aksine organize bir yapıya sahip değiller, aralarında kendi sorunlarını çözecek bir müesseseleri bulunmamaktadır. Hatta bir Azzabe teşkilatına da sahip değildirler. İbadîlerde Azzabe Teşkilatı konusunda bir eseri bulunan Dr. Ferhat son zamanlarda bu müesseseyi Tunus'ta yeniden faaliyete geçirmek için çaba sarf etse de henüz bunu başaramamış. Hatta bunun dışında da çok ciddi müesseseleri bulunmamaktadır. Başkent Tunus'ta kendilerine ait olan Hentati Camii'nin dişında bir de bir buçuk yıl önce Dr. Ferhat tarafından kurulan Cemiyyetu Cirbe Li't-Tevasul adında bir müesseseleri vardır. Buranın kurucusu olan Dr. Ferhat, Seyyid Kutub'un arkadaşı Dr. Amr en-Namî'nin de dostudur. Burada bir de kütüphane mevcuttur. Cezayir İbadîleri, Azzabe Teşkilatı'na sahip olduğu için cemaati bir arada tutmuş, cemaatin asıl yapısına zarar veren şahısların zararları vela (Velâye) ve bera (Berâe) ilkesi ile defedilmiştir. Dahası Cezayirlilerin özellikle Fransız işgaline karşı duruşları ve Tunus'a göre işgali benimseyerek kabul etmemiş olmaları onları Fransız kültürüne mesafeli hale getirmiştir. Tunus'a gelince gerek bu müesseseye sahip olmamaları, gerekse Fransız kültürünü benimsemiş olmaları onları tamamen kendi kültürlerinden koparmıştır. Ancak Tunus İbadîleri ile Sünnîlerin ilişkilerinin iyi olması, hatta aralarındaki evliliklerin son derece sıradan bir hadise olması oldukça olumlu husus. Tunuslu İbadî aileler dişarıya daha açıklar. Cemaat tutuculuğu gelişmediğinden dışarıya kız verdikleri gibi çok rahat bir şekilde kız da almaktadırlar. Son zamanlarda Umman Sultanlığı ile iyi ilişkiler geliştirmişler, Umman Sultanlığ başta Baruni Kütüphanesi olmak üzere bunların müesseselerine ciddi anlamda yardımlar yapmaya başlamıs, bu durum onlarda bir cemaat bilincinin oluşmasına ve mezhep 
bilincinin doğmasına katkı sağlamıştır. Tunus'ta tanıştığımız bazı araştırmacılar ise özellikle devrim öncesi takip edilen politikanın mezhepler üstü olması İbadî bilincinin gerilemesinde etkili olduğunu iddia etmişlerdir.

Cezayir İbadîleri dinlerine son derece bağll, hanımlar son derece mütesettire iken Tunus İbadîleri ise içlerinde dini duruşlarını muhafaza edenler var gibi görünse de çoğunluğu sair Tunuslular gibi son derece rahatlar. Cezayir'de hanımlar hayatın pek içerisinde değiller, dini eğitim ve aile yaşamına uygun bir eğitim alırlarken, Tunus'ta İbadî hanımlar her alanda varlar. Amr en-Namî'nin Cirbe ve Nefusa İbadîlerini anlatırken ifade ettiği gibi ellerinde önemli miktarda yazmalar olmasına rağmen hala bunları diğer araştırmacılarla paylaşacak kadar kendilerini rahat hissetmemektedirler. Bütün İbadîlerde olduğu gibi Tunus'ta da cemaatin önemli bir kısmı ticaretle uğraşmaktadır. İbadîlik çalışan bir araştırmacının bize verdiği bilgiye göre bu durum özellikle devrim öncesinde kontrol altında tutulmalarına neden olmuştur. Zira devlet onların ticareti kontrol altında tutarak devlete zarar verebileceğini düşünmüş ve kendilerini murakabe altında tutmuştur. Hatta bu araştırmacı kendisinin de İbadîlik çalıştığı için bu dönemde bazı sıkıntılar yaşadığını aktardı. Her ne kadar devrim sonrasinda bazı rahatlamalar olsa da aynı araştırmacının verdiği bilgilere göre Dr. Ferhat hala gözetim altında olup faaliyetleri izne tabidir. Yurt dişına bile ancak izinle çıkabilmektedir. Bu da henüz tam bir özgürlüğün oluştuğunun söylenemeyeceğini göstermektedir.

Tunus'ta İbadîlerin açıkça kendilerini ifade etmeleri ve kendilerine ait müesseseleri inşa etmeleri devrimden sonra mümkün olabilmiştir. Günümüzde kendilerini açıkça İbadî olarak tesmiye etmektedirler. Nitekim bu sene ilk kez kendilerine ait bir sempozyum düzenlemissler. Sempozyumun konusu ise "İbadilerde Siyer yazıc1lığı" bir başka ifade ile "İbadilerin tarih algısı". Önümüzdeki yıl da bir sempozyum düzenleyeceklerini söylediler ve bizi de bu sempozyuma davet ettiler. Hatta İslami İimler Dergisinnin İbadîyye sayısı burada duyulmuş bu açıdan da çok memnun olmuşlar. İlk kez Türkiye'den Cirbe'ye kendileriyle görüşmek üzere bir ekibin geldiğini söylediler 
ve buna memnuniyetlerini dile getirdiler. Hatta dergi bağlamında ortak projeler de yapmak istediklerini söylediler.

Tunus'ta İbadî cemaatin aynı zamanda bir de temsil sorunu var. Kendi aralarında organize olmadıkları için ciddi bir cemaat demek zor gibi görünmektedir. Ancak bununla birlikte ticaretle iştiğal eden bir ekip olmaları onları birbirlerine bağlamış ve birlikte hareket etmelerini sağlamıştır. Bir başka ifadeyle dini bir cemaatten ticari bir cemaate dönüşmüşlerdir. Onun için dinî duyarlılıkları veya dinî anlayışları aynı derecede değildir. İçinde Burgiba çizgisinde olanlar olduğu gibi dinî hassasiyetleri fazla olanlar da vardır. Hatta Cirbelilerin yaklassık yüzde beşi Fransa'da yaşamaktadırlar. Bunların ise dinî cemaatle hiçbir alakaları kalmamıştır. Bununla birlikte aralarında toplumsal bir örfün olduğu bu örf kapsamında birbirleriyle ilişkilerini sürdürdükleri söylenebilir. Ancak mezhep ilişkilerinin çok güçlü olduğu söylenemez. Yani son derece sathî bir bağlllıkları söz konusudur. Nitekim Cirbe'nin bir turizm adası haline gelmesi de bu anlayışın bir yansımasıdır.

İbadîlerin temelde Nukkar ve Vehbiler olarak iki gruba ayrıldığını yukarıda söylemiştik. Nukkarîler, Tunus dışında başka bir yerde bulunmamaktadır. Vehbilere göre Nukkariler gizlenmekte kendilerini açıkça ifade edememektedirler. Ancak Tunus'ta görüştüğümüz araştırmacılar Nukkar'in gizlenmediğini ancak Vehbilerin bunlarla görüşülmesini istemediklerini, bundan dolayı da böyle düşündüklerini söylediler ve onların Cirbe adasının güney tarafında hala yaşadıklarını ifade ettiler. Aynı araştırmacılara göre Tunus İbadîyyesi arasında liderlik hususunda bir çekissme bulunmaktadır. Bu nedenle en azından üçe ayrılmış vaziyettedirler. Ancak biz bunu çok fazla hissetmemekle beraber böyle olmadığına dair bir veri de elde edemedik.

\section{$16 / 04 / 2015$}

Sabah Kayrevân'a gitmek için bir araç kiraladık. Tunus'un günümüzde de büyük kentlerinden biri olan Kayrevân, başkent Tunus'un yaklaş1k $150 \mathrm{~km}$ güneyinde olup, nüfusunun 546.000 olduğu ifade edilmektedir. Bu kadim kente, yol kenarlarında Arapların 
"tin eş-şevki" dedikleri kaktüs ağaçlarının eşliğinde iki saatlik bir araba yolculuğundan sonra ulaştık.

Şehre girerken bizi Ağlebîler döneminde İbrahim b. Ağleb tarafından inşa edilen su sarnıçları karşıladı. Tunus'ta bu su sarnıçlarına fiskiye denilmektedir. Su sarnıçlarının olduğu bölge günümüzde koruma altına alınmıştır. Orayı gezerken o bölgede çalışan bir görevli bize şimdiki Cumhurbaşkanımız Sayın Recep Tayyip Erdoğan'ın da Gannuşî ile birlikte buraya geldiğini anlattı. Bu arada Türklerin Katar ile birlikte DAİŞ'e destek verdiğini, böylelikle İran'n ilerlemesini sağladıklarını söyledi. Bunun doğru olmadığını, terörün en çok bizi etkilediğini, teröristlere destek vermemizin düşünülemeyeceğini anlattım. Ancak susmakla beraber, pek ikna olduğunu sanmiyorum. Su sarnıçlarından sonra şehrin merkezine doğru ilerlerken İbn Cezzâr adını taşıyan Kayrevân hastanesini görünce en azından tarihi şahsiyetlere sahip çıktıklarını düşünüp mutlu oldum. Bilindiği gibi İbn Cezzâr Kayrevân'ın yetiştirdiği en önemli tabiptir. Zaten Kayrevân, Kuzey Afrika'nın en önemli tıp merkezlerinden biri olarak kabul edilmektedir. Son zamanlarda buranın yetiștirdiği büyük hekimler ve sahip olduğu tıp geleneği hakkında Tunus'ta bir kongre düzenlenmiş ve bildirileri de yayınlanmıştır. ${ }^{10}$

Müslümanlar tarafindan inşa edilen ilk tarihi şehirlerden biri olan Kayrevan, Emevilerin İfrikiyye valisi Ukbe b. Nafi' tarafından hicri 50 yılında, bir cunud, bir başka ifade ile askeri karargâh olarak kurulmuş olup inşaatı beş y1l sürmüştür Tunus'un orta bölümünde kalan Kayrevân, sahile uzak bir noktada inşa edilmiştir. İnşa edildiği yer oldukça stratejiktir. Zira bir taraftan gerektiğinde rahat denize ulaşmak, diğer taraftan da deniz yolu ile yapilacak saldırılardan kısmen uzak kalmak ve bu kabil çatışmalardan zamanında haberdar olmak murad edilmiştir. Kuzey Afrika'nın idare merkezi olarak kurulan Kayrevân, inşa edildiği tarihten itibaren heterojen bir yapıya sahipti. Bir taraftan Kuzey ve Güney Araplarına

10 Medresetu el-Kayrevân et-Tibbiye ve mevkifuha mine't-trbi'l-Arabi, Vizaretu'tTa'lim ve Buhus el-ilmi Camiatu'z-Zeytune, Merkezu Dirasat el-İslamiyyebi'lKayrevân. 
ev sahipliği yaparken, diğer taraftan da Horasan bölgesinden buraya tehcir eden askerlere, öte taraftan da Emaziğ kökenli Müslümanlara ev sahipliği yapmıştır. Merkezine inşa edilen Cami ve Daru'lİmare ile tipik bir İslam şehri olan Kayrevân'da, aynen Kufe ve Basra örneğinde olduğu gibi her kabile veya ırkın kendine özgü mahallesi mevcuttu. Bu da bir taraftan çatışmayı doğururken diğer taraftan da eşine ender rastlanan bir ilmi sıçramanın oluşmasını sağlamıştır. Hele hele günümüze kadar gelmeyi başaran Kayrevân Camii asırlarca bir medrese olarak kullanılmış ve yörenin İslamlaşması üzerinde önemli bir etkiye sahip olmuştur. Bu önemli mabet, Cami' el-Kebir olarak da bilinmekle beraber günümüzde Camiu Sidi Ukbe olarak isimlendirilmektedir. Bu cami Kayrevân'a özellikle Emaziğler tarafından yapılan saldırılarda zarar görmüş, hatta sonraki dönemlerde yeni baştan inşa edilmiştir. Onun için otantikliğini kaybetmekle beraber hala en önemli İslam mimari eserlerinden biri olarak kabul edilmektedir.

Caminin kare gövdeli kalın minaresi Kuzey Afrika'nın tamamında benzer bir şekilde karşımıza çıkmaktadır. Revaklı avlusunun ortasında oyulmuş ve camii görevlisi tarafından su konan bir alan vardı. Ne olduğunu sorduğumda buraya güvercinler için su koyduklarını söyledi. Bu da güvercinlere minnettarlığımızın Kayrevân'da da devam ettiğini göstermektedir. Mihrabı ve kuzeyindeki ahşaptan yap1lan kapalı alanın ahşap işlemeleri muhteşem olan cami İslam mimarisinin gözde örneklerinden biri olarak kendisinden sonra kurulan birçok caminin mimarisini de etkilemiştir. ${ }^{11}$

Kayrevân İbadî tarihi açısından da son derece önemli bir geçmişe sahiptir. Zira Seleme b. Sa'd'in talebeleri tarafından kurulan ilk İbadî cemaatlerinden biri burada küşat edilmiştir. Bu ders halkasında yetişenlerin bazısı daha sonra Basra'ya gönderilmiş ve tarihte İbadîlerin imamı olarak tebellür eden Ebu Ubeyde'nin ders halkas1-

11 Kayrevân Camiisi ile diğer tarihi eserler hakkında geniş bilgi için bkz. Dirasat fi tarih el-Kayrevân, (Editör Necmuddin el-Hentatî) neşr: Vizaretu't-Ta'lim ve Buhus el-ilmi Camiatu'z-Zeytune Merkezu Dirasat el-İslamiyye bi'l-Kayrevân Vahdetu Bahs Tarih el-Kayrevân, 2009. 
na iştirak etmişlerdir. Burada yetişen ve adına Hameletu'1-ilm denilen beş kişi daha sonra Kuzey Afrika'ya dönmüştür. Bunlardan imam olarak görevlendirilen Ebu'l-Hattab'ın gayretleri ile yörede ilk İbadî emirlik kurulmuştur. Merkezi Trablus olan bu emirlik, daha sonra Kayrevan, Kâbis ve Nefzâva'yı da hakimiyeti altına almıştır. Ebu'l-Hattab merkez Trablus'ta kalırken; Kayrevân kadılığı ve valiliğine ise Abdurrahman b. Rüstem'i atamıştır. Dolayısıyla ziyaret ettiğimiz Kayrevan'a Rüstemi Devleti'ni kuran şehir şeklinde bakmak da mümkündür. Zira burada bir süre valilik yapan Abdurrahman b. Rüstem, bölgeye gelen Muhammed b. Eşas el-Huzaî komutasındaki Abbasî ordusuna yenilmiş ve Kayrevan'ı terk etmek zorunda kalarak beraberindeki İbadîlerle birlikte Cezayir içlerine çekilmiş ve burada tarihi Tahert kentini kurarak Rüstemi Devleti'nin merkezi haline getirmiştir. Kayrevân daha sonra Ağlebî (808-909) hanedanının hakimiyetine geçmiştir. Onlar döneminde en parlak günlerini geçiren bu tarihi şehir, daha sonra Fatımilerin hâkimiyeti altına girmiştir. Yöredeki İbadîlerin toparlanması sonucunda 332/944 tarihinde Ebu Yezid en-Nukkarî'nin hâkimiyetine girmiştir. Bundan, o dönemlerde yörede daha çok Nukkarî İbadîlerin varlığ1 anlaşılmaktadır. Ancak günümüzde Nukkariye mezhebine mensup olanların azınlıkta kaldığı söylenmektedir. Şehir daha sonra Ziriler, Muvahhitler ve Hafsilerin hakimiyetine girmiştir.

İslam kültür ve medeniyetinde önemli izler bırakan Kayrevan, sadece Kuzey Afrika'nın değil aynı zamanda Afrika'nın sair bölgeleri ile Endülüs'ten öğrencilerin de rağbet ettiği; gelip eğitim gördüğü, bir mekan olarak bilinmektedir. ${ }^{12}$ Nitekim birçok ilim adamı da yetiştirmiştir ki, eğitim tarihçisi olarak kabul edilen İbn Sahnûn, Huşenî, İbnu'l-Cezzâr, Kabisî, Kazzâz, Raik el-Kayrevânî ile Husrî ve İbn Reşik el-Kayrevânî bunlardan sadece bir kaçıdır. Yanı sıra yörenin ticaret tarihinde de önemli yere sahip olduğu bilinmektedir.

12 Geniş bilgi için bkz. Muhammed b. Zeytun, el-Kayrevân ve devruhu fi hadareti’l-İslamiyye, Kahire 1988. 
Nitekim Kayrevân orta Afrika ile Rustemiler ve Endülüs arasında da aracı rol oynamıştır. ${ }^{13}$

Kayrevân Ukbe b. Nafi' camisinin etrafı geleneksel Kayrevân evleri ile kuşatılmış vaziyettedir. Hepsi günümüzde kullanılmakta olan bu meskenler, sanki tarihin içerisinden çıkmış, size arzı endam etmektedirler. ${ }^{14}$ Daracık sokaklardan geçerken en çok evlerin kapıları dikkatimizi çekti. Kapıların üzerinde bulunan üç tokmak Osmanlı kentlerimizde kullanılan geleneğin burada da varlığını göstermektedir. $\mathrm{Bu}$ tokmaklardan biri erkekler, diğeri hanımlar, bir başkası ise çocuklar tarafından kullanılmaktaydı. Dolayısıyla tokmağın sesinden evin içindekiler kimin geldiğini anlayabilmekteydiler. Tokmakların şekli ise hangi evin hangi kabile efradına ait olduğunu anlatmaktadır. Örneğin Emaziğlerin evlerinin tokmakları el şeklinde iken, Arapların tokmakları ise küt şekildedir. Diğerlerinin tokmakları ise halka şeklindedir. Kayrevân kapıları,n Gırnata'da Müslüman mahallesinde gördüğümüz kapılarla neredeyse bire bir aynı idi. Zaten Kayrevân camileri de aynen Endülüs camilerini andırmaktadır. Özellikle de Savmia denilen kare şeklinde minareler.

Tunus'un en özgürleri ise kedilerdir. Zira kapılarda kedilerin özgürce giriş ve çıkışını sağlamak için delikler bırakılmış. Kediler bu deliklerden istedikleri mekâna özgürce ulaşabilmektedirler.

Kayrevân, cami, mescit ve medreselerle dolu bir kenttir. Tarihi şehir merkezinde gezerken onlarca cami ve mescitle karş1laşıyorsunuz ki bunların bir kısmı hala kullanılmaktadır. ${ }^{15}$ Bunların tamamının faal olduğu dönemleri düşündüğünüzde şehrin ne denli canlı bir ilmi hayata sahip olduğunu tahmin etmek zor değildir. Bu cami-

13 Geniş bilgi için bkz. Habib Cenhanî, el-Kayrevân abre izdihari'l-hadareti'lİslamiyyefi'l-Mağrib,Tunus 1968.

14 Kayrevân evleri hakkında geniș bilgi için bkz. Nihâd b. Şa'ban, "Dirasatun mi'mariyye ve zuhrufiyye li nemâzic düver atika bi medineti'lKayrevân"Dirasat fi tarih el-Kayrevân, (Editör Necmuddin el-Hentatî) neşr: Vizaretu't-Ta'lim ve Buhus el-ilmi Camiatu'z-Zeytune Merkezu Dirasat elİslamiyye bi'l-Kayrevân Vahdetu Bahs Tarih el-Kayrevân, 2009, 13-63.

15 Kayrevân camileri ile ilgili geniş bilgi için bkz. Necva Osman, Mesacidu Kayrevân: Le Moque de Kairouan, D1meşk 2000. 
lerden en dikkat çekici olanı ise sahip olduğu üç kapıdan dolayı Mescidu Selaseti Ebvâb denilen mabed idi. Üzerindeki kitabeye göre 644 tarihinde mimar Muhammed b. Haynûn el-Meafirî elEndelusî tarafından inşa edilen caminin kapılarından biri erkeklere, diğeri kadınlara, sonuncusu ise çocuklara ayrılmıştır.

Şehrin ortasında yüzlerce yıl öncesine dayanan ve aynen o gün olduğu gibi günümüzde de devenin dönmesi ile yirmi metre derinlikten su çıkaran bir kuyu bulunmaktayd1. Bu gün turistlere iki dinar karş1lığında su sağlayan bu kuyunun üzerinde 160/790 tarihinin bulunması dikkat çekiciydi. Son dönemde Kayrevân'da yap1lan kazılarda ortaya çıkarılan bu kuyunun adı Barrouta idi. Arapça olmayan bu kavramın Emaziğce olduğunu tahmin etmekteyiz.

Kayrevan çarşısı tarihi şehrin merkezinde yer almaktadır. Bu çarş1 günümüze önemli oranda ulaşmıştır. Nitekim burada gezerken serracin çarşısı, neccarin çarşısının kazındığı taş levhaları inceleyerek ilerlemektesiniz. ${ }^{16} \mathrm{Bu}$ gün bu çarşılarda bu işler yapılmasa da geleneksel tarzda üretim yapan bazı atölyeler hala mevcuttur. Geleneksel kumaş üretenler, geleneksel terziler ve diğerleri varlıklarını önemli oranda korumaktadırlar.

\section{Cirbe}

16/04/2014 günü akşam Cirbe'ye ulaştık. Toplam 512 kilometre kare yüzölçümü olan Cirbe adasına sahilden yaklaşık bir lira gibi komik sayılacak bir ücret ödeyerek geçiş yaptık. Araç vapuruna bindiğim zaman kendimi Pendik'ten Yalova'ya geçiyor gibi hissettim. Güzel, sakin ve kısa bir yolculuktan sonra karşıya ulaştık. Ada, Akdeniz'in büyük adalarından biri olarak bilinmekte olup; Tunus'un ise en büyük adasıdır. Bir tarafından diğer tarafına $20 \mathrm{~km}$ olduğunu söylediler. Ada halkı aynen diğer İbadîler gibi ticaretle uğraşmaktadır. Hatta bundan dolayı Tunus'ta "cirbî” kelimesi Ceza-

16 Tarihi Kayrevân çarşısı ile ilgili geniş bilgi için bkz. Abdurrahman Barunî, "Esvaku'l-Medineti'l-Kayrevân fi'l-Asri'l-Vasit min Hilali'l-Mesadir ve'l-Âsâr", Dirasat hadariyye havle el-Kayrevar, (edit: Necmuddin Hentati), Vizaretu'tTa'lim ve Buhus el-ilmi Camiatu'z-Zeytune Merkezu Dirasat el-İslamiyye bi'lKayrevân, 2015, ss.77-123. 
yir'deki "mizabî" kelimesiyle eş anlamlı yani tüccar manasında kullanılmaktadır. ${ }^{17}$ Hicri 47 senesinde Müslüman askerler tarafından fethedilen Cirbe adası İbadi tarihi açısında çok önemli bir yere sahiptir. ${ }^{18}$

Adanın temelde üç büyük merkezi bulunmaktadır. Bunlar Hummetu's-Sûk, Âcim ve Meydûn'dur. Bunların yanı sıra adada birçok da köy vardır. Başkent Tunus'tan gelirken Âcim'den girdiğimiz adanın merkezi Hummetu's-Sûk'dur. Halk arasında daha çok Humme olarak tesmiyye edilen bu yerlessim birimi, Osmanlı döneminde de merkez olarak kullanılmıştır. Nitekim burada iki Osmanlı paşasının da türbesi bulunmaktadır. Bu türbe son zamanlarda TİKA tarafından restore edilerek ziyarete açılmıştır. Yine adanın önemli kalelerinden biri olan Hisn el-Kebir'in Osmanlı tarafindan inşa edildiği rivayet edilmektedir. Züheyr et-Tiğlatî̀ye göre burası Turgut Paşa'nın İspanyollara karşı kazandığı savaştan sonra inşa edilmiştir. İbadîler bu savaşı Osmanlı ile ilk ittifakları olarak görmektedirler. Hisn el-Kebir'in batısında Burc el-Cemacim yer almaktadır. Burada İspanyolları yendikleri savaşın anısına bir anıt dikilmiştir. ${ }^{19}$ Rivayetlere göre savaşta öldürülen İspanyol kelleleri bir araya toplanarak burç oluştuğu için buna "Kafatasları Burcu" anlamına gelen Burcu Cemâcim denilmiştir. Humme'de Osmanlı döneminden kalma bir de cami mevcuttur. Bu camiye günümüzde Mescit Turk (Türk Camisi) denilmektedir. Halk arasında Osmanlı dönemi ile ilgili olumlu söylenceler de yer almaktadır. Adada İspanyollar ile Fransızlar tarafından yapılan mekanlar da vardır. İspanyollar tarafından inşa edilen Burc Gazi Mustafa'nın önünde günümüzde Osmanlı döneminden kalma toplar sergilenmektedir. Bu

17 Cirbe adası İbadîleri ile ilgili geniş bilgi için bkz. Muhammed Mürîmî, İbadîyyetu Cezireti Cirbe hilale'l-asri'l-hadis, Tunus 2005.

18 Konu ile ilgili geniş bilgi için bkz. Said b. Yusuf el-Barunî, "Sefehâtun halide min tarih Cirbe ba'de'l-fethi'l-İslamiyyi min sene 47 ilâ sene 1298 hicri”, Dirasât havle Cezireti Cirbe, Cemiyetu Siyaneti Cezireti Cirbe, 120-148.

19 İspanyolların Cirbe adasına saldırıları hakkında geniş bilgi için bkz. Abdulkerim el-Kafasî, "el-Hamletu'l-İsbaniyye ala Cezireti Cirbe", Dirasât havle Cezireti Cirbe, Cemiyetu Siyaneti Cezireti Cirbe, Cirbe ?, 56-64. 
burcun etrafinda var olan su depoları ise Osmanlı döneminde inşa edilmiştir. Bu depolar içme suyu sıkıntısı çeken Cirbe'de yağan yağmur sularının toplanması için kullanılmıştır. Adanın muhtelif yerlerinde kazılan kuyulardan elde edilen sular ise tuz oranının yüksekliğinden dolayı içmeye uygun değildir.

Cirbe'ye geliş amacımız buradaki İbadîlerle görüşmek ve tarihi mekânlarını görmekti. Yukarıda da ifade ettiğimiz gibi Cirbe, İbadî tarihi açısından önemli bir konuma sahiptir. Çünkü Rüstemiler yıkıldıktan sonra dağılan İbadîlerin bir kısmı bu adaya sığınmış ve asırlarca burayı kendilerine yurt edinmişlerdir. Günümüzde bile nüfusunun yüzde altmışını İbadîler oluşturmaktadır. Tamamına yakını Emaziğ kökenli olan bu İbadîller, Kuzey Afrika'nın yerli halkıdır. Tanımlamayı ve tepeden bakmayı seven batılılar, özellikle Romalılar bu ulusun barbarlar olduğuna hükmetmiş ve onlarla ilgili olarak "barbar" kavramını kullanmıştır. Bu kavram daha sonra "Berberî" kavramına dönüşmüş ve Müslüman Araplar tarafından da benimsenerek kullanılmıştır. Dahası kendileri tarafından da kullanılır olmusstur. Kabileler halinde varlıklarını idame ettiren Emaziğlerin bilinen en meşhur kabileleri Levâte, Hevvâre, Nefûsa, Zevâğa, Kitâme, Zennâte, Lemmâye'dir. Cirbe'de Yahudilerin yaşadığı da bilinmektedir. Harra el-Kebir'in çevresinde yaşayan Yahudilerin burada havraları da mevcuttur. Cirbe'de bu iki kitlenin dişında kalanlar ise Araplar olup Malikî mezhebine mensupturlar. Genelde Tunus, özelde ise Cirbeliler, Cezayirlilerin aksine Emaziğce'yi unutmuş vaziyettedirler. Ancak Tunus'un güney taraflarında Emaziğce'yi henüz unutmayan bazı İbadîlerin bulunduğu kaydedilmektedir.

Cirbe'de bazı önemli İbadî müesseseler bulunmaktadır Baruniyye kütüphanesi ile Şeyh Yakup Müessesesi bunların başında gelmektedir. Kimi araştırmacılara göre bu iki müessese ile Dr. Ferhat elCa'birî arasında İbadî cemaatinin liderliği konusunda bir çekişme mevcuttur. Cirbe'deki mihmandarlığımızı, İslamî İimler Dergisìnin İbadî sayısında bir yazısını neşrettiğim Züheyr Tiğlat yaptı. Züheyr, bizi Hummetu's-Suk denilen Cirbe adasının merkezinde karşıladı. Zaten İbadîlerin önemli bir kısmı da burada yaşamaktadır. Burada 
el-Merkez es-Sekafî el-Mutavassitî adında bir İbadî müessesenin de başkanlığını yapan Züheyr, kadim dönemde Cirbe'nin önemli bir kısmının Nukkariler olduğunu, bugün Tunus'ta yaşamadıklarını dolayısıyla bu mezhebe mensup olanların akıbetinin ne olduğunu sorduğumda adanın temelde ikiye ayrıldığını yarısının o dönemlerde Nukkariler, diğer yarısının ise Vehbiler olduğunu; Nukkarilerin özellikle bin sekiz yüzlerin sonunda Muradiler tarafından yapılan parasal desteklerin akabinde Malikî mezhebini kabul ettiklerini söyledi. Vehbilerin ise varlıklarını koruduklarını ilave etti. Ancak bir sonraki gün ise bunların bazısının gizli gizli varlıklarını koruduklarını ifade ederek aslında hala yaşadıklarını kabul etmiş oldu. Züheyr'in başkanlığını yaptığı merkez, Fransızlar döneminden kalma bir binada faaliyet göstermektedir. İki katlı binanın üst katının bir kısmı kütüphane haline getirilmiştir. Aynı katta okuma salonları ve de sınıflar bulunmaktadır. Kütüphanenin bir salonu ise dijital kütüphane haline getirilmiştir.

Humme Belediyesi ile Turgut Reis Belediyesi arasından kardeş belediyye antlaşması yapılmıştır. Bizi gezdiren ve aynı zamanda Züheyr hocanın müessesesinde görev yapan adaşım Mahfuz Dahman bu belediyeden emekli olmuş Medine el-Münevvere Üniversitesi mezunu bir ilim adamıdı. Son derece güzel bir Arapçası vard1. Suudi Arabistan'da eğitim görebilen Dahman örneği İbadîlerin Medine gibi Sünniliğin, dahası Sufiliğin merkezi olan bir mekanda eğitim gördüklerini göstermesi açısından dikkat çekiciydi.

Cirbe'de İbadîlere ait pek çok cami bulunmaktadır. ${ }^{20}$ Bunların en eskisi ise Cami'el-Kebirdir. el-Haşan köyünde bulunan bu cami, hicri dördüncü asırda Ebu Misver tarafından inşa edilmiştir. Aynı zamanda Mescidu'1-Medrese ve Camiu Ebi Misver olarak da isimlendirilen bu caminin etrafında bir de medrese bulunmakta imiş. Zaten bu ismi de söz konusu medreseden almışt1. Cirbe İbadî Ekolü'nün bu cami etrafında şekillendiği kaydedilmektedir. Dolayısıyla

20 Bu mescidlerin bir kaçı ve mimari yapılarıyla ilgili geniş bilgi için bkz. Riyâd el-Murabit, "el-Kiymetu'l-fenniyye ve't-tarihiyye li mesacidi Cirbe", Dirasât havle Cezireti Cirbe, Cemiyetu Siyaneti Cezireti Cirbe, Cirbe ?, 74-78. 
burada yetişen ulema Cirbe'nin yanısıra diğer bölgelere de İbadîliğin yayılmasında pay sahibi olmuştur. ${ }^{21}$ İbadî camileri ile Sünni camileri birbirine benzememektedir. İbadî camilerinde kısa ve küt minare kullanılırken, Sünni camilerde ise uzun ve kare minare kullanılmaktadır. İbadîlere göre minarenin kısa olması alçak gönüllülüğü simgelemektedir. Minare biraz uzun, namazın kılındığ caminin kubbesi ondan az daha kısa, mihrab ise daha düşük kota sahip olarak inşa edilmiştir. Züheyr et-Tiğlat'a göre minare, kubbe ve dişa doğru açık bir bombe tarzında düşünülen mihrab, Allah lafzı celalini simgelemektedir. Camii el-Kebir'in avlusunda aynı zamanda yazlik bir musalla da mevcuttur. İbadî camilerinin tamamında yazlık musalla yer almaktadır. Vehbilerin camileri ile Nukkarilerin camileri de birbirlerinden farkll11k arz etmektedir. Nitekim Vehbilerin minareleri camilerin kuzey batı tarafında; Nukkarilerinki ise kuzey doğu tarafından inşa edilirlerdi.

Eberda Camii ise Bezin bölgesinde olup İbadîlerin Cirbe'deki en önemli mabedlerinden biridir. Bu cami İbadîlerin kendilerini açıkça ifade edemedikleri, özgür davranamadıkları, gizlendikleri bir döneme yani kitman dönemine aittir. Cami zeytinliklerin ortasında, yerin altına inşa edilmiştir. Kapadokya bölgesinde Romalıların korkusuyla yerin altına inşa edilen kiliseleri hatırlatan bu mabet, imanın gücünü göstermesi açısından etkileyiciydi. Üzeri yağmur yağdığ1 zaman suyun akışını sağlamak amacıyla kils ile sıvanmıştır. Bu yağmur suları hemen yanına inşa edilen sarnıçta toplanır ve içme suyu olarak kullanılırdı. Kils ile sıvanan bu bölüm aynı zamanda yazları musalla olarak da kullanılıyordu. 1940'larda buraya bir şadırvan inşa edilmiştir, zeytinliklerin ortasında olduğu için bir hela düşünülmemiştir. 1950 yılına kadar ibadete açık olan Eberda Camii, günümüzde kullanılmamaktadır. Yakınlarında ise aynı tarihlerde yapıldığı ifade edilen bir zeytinyağı atölyesi yer almaktadır. Bu atölyenin burada inşa edilmiş olması da dışarıdan gelen yabancılara

21 Bkz. Muhammed Koca, “Eb'adu'l-Hadariyye li Cami’ Ebî Misver fi Cezireti Cirbe", Dirasât havle Cezireti Cirbe, Cemiyetu Siyaneti Cezireti Cirbe, Cirbe ?, 78-89. 
buranın bir zeytinyağı atölyesi ve müştemilatı olduğu izlenimi vermek içindir.

Yine Cirbelilerin verdiği bilgiye göre Dammar sıradağlarında (bu dağlar Matata'dan başlayıp Cebel-i Nefusa'da son bulmaktadır) benzer birçok mabet hala kullanılmaktadır. İçine girdiğimiz camii son derece serin idi. Dışarda sıcaklık 35 derece olmasına rağmen içeride sıcaklık ancak on altı derece civarındaydı. Tabî̀ ki bu camilerin bir de İmam Ebu Ubeyde'nin serdabını yani ilk medreseyi çağrıştırmasının da ayrı bir önemi vardır. Bilindiği gibi İmam Ebu Ubeyde'de muhalifi Emevilerden çekindiği için dişarıdan kaffaf atölyesi olarak görülen ancak işin özünde bir medrese olan serdabda talebelerini yetiştirmiş; hatta Hameletu'l-İlm denilen ve İbadîliği Kuzey Afrika'ya yayan talebeleri de burada eğitmiştir.

Devrimden sonra Cirbeliler kendi mahallelerinde yeni bir camii inşa etmişler. Adı Mescidu Takva olan bu mabedin minaresinin olmaması dikkat çekici idi.

Cirbe adasının deniz sahilinin neredeyse tamaminda adına Hisn denilen ribatlar kurulmuştur. Bu ribatlarda görev yapan şahıslara ise murabıt denilmektedir. Tasavvufi bir kavram gibi görünse de aslında murabit ifadesi Ribated-Difa'i yani savunma ribatı denilen bu müesseselerde görev yapan gönüllüleri ifade etmektedirler. Bu ribatlardan bir tanesini; Hısn el-Ecmer'i gezdik. Aynı zamanda cami olarak da kullanılan ribat'ta düzenli olarak insanlar yaşar ve deniz tarafından gelebilecek düşmanı gözlerlermiş. Ribatın bir köşesine inşa edilen yüksek kulelerde ise düşman geldiğinde ateş yak1larak gelişleri halka haber verilirmiş. Böylece halkın hazırlık yapması sağlanırmış. Tunus İbadîlerine göre azzabe teşkilatının mensupları tarafindan bu ribatlara bakılır, hatta azzabe tesskilatı mensupları zaman zaman buraları teftiş eder, duruma göre uygun strateji belirlerlermiş.

Cuma namazını, yine bir İbadî Camisinde Cami' eş-Şeyh'te kı1dık. Bu cami, Cami' el-Kebir'den çok sonra inşa edilmiş bir mabettir. Cami hınca hınç dolu idi. İbadî camisi olmasına rağmen cemaatin içerisinde Malikiler de vard1. Cuma hutbesinin konusu "umut" 
idi. Hoca efendi insanların, özellikle de gençlerin ümitlerini yitirdikleri günleri yaşadıklarını, bunun gençleri çok etkilediğini beraberinde hayal kırıklığı, umutsuzluk, hayattan soğuma ve depresyon ile intiharı getirdiğini söyledi. Son dönemlerde intihar edenlerin sayısında ciddi bir artışın olduğunu, Tunus'ta intihar oranlarının birçok ülkeden daha yüksek olduğunu ilave etti. Dahası bu umutsuzluğun insanlar arasında uyuşturucu kullanımını da hızlandırdığını söyledi. Tunus'un uyuşturucu kullanımında da yüksek bir orana sahip olduğunu anlattı. Sonuç olarak da gençlere ve özellikle çocuklara umut aşılanması gerektiğinin altını çizdi.

Cirbe'de büyük bir kısmı İbadîyye mezhebine mensup olan bir adada, İbadîyye mezhebine mensup bir imam tarafından böyle bir hutbenin irad edilmesi son derece önemlidir. Zira büyük günah işleyen şahsı cemaat dışı kabul eden ve tövbe etmediği sürece İslam'a dönmeyeceğine inanan bir düşünce ekolüne mensup gençler arasında uyuşturucu ve intiharın yaygin hale gelmesi Tunus İbadîlerinin yaşadığı kırılmayı ifade etmesi açısından dikkat çekicidir. 
